\title{
THE IMPACT OF GOVERNMENT POLICIES ON THE COMPETITIVENESS OF CLOVE COMMODITYIN TOLITOLI REGENCY: MULTI PERIOD PAM APPROACH
}

\author{
Adnan Putra Pratama1*, Dwidjono Hadi Darwanto ${ }^{2}$, Masyhuri ${ }^{3}$ \\ 1,2,3 Department of Agricultural Socio-Economics, Faculty of Agriculture, Universitas \\ Gadjah Mada, Yogyakarta, 55281, Indonesia \\ *Corresponding author: adnanputra92@mail.ugm.ac.id
}

Submitted: 29 April 2020; Revised: 8 July 2020; Accepted: 9 August 2020

\begin{abstract}
This study aims to determine the competitiveness of clove commodities in Tolitoli Regency in terms of competitive and comparative advantages and to determine the impact of government policies on the sustainability of clove farming in TolitoliRegency. The method of determining respondents used a simple random sampling method and obtained as many as 87 samples of clove farmers. The data analysis method used was the Multi-Period PAM (Policy Analysis Matrix). The results of this study indicate that the clove commodity in Tolitoli Regency had competitiveness in terms of competitive and comparative advantages with a PCR value of 0.415 and DRCR 0.412 . The impact of government policies on the output of clove farming in Tolitoli was protective against farming systems with an NPCO value of 1.088, but tent to be weak. While on the other hand, the impact of government policies on cl ove farming inputs was unprotective with an NPCI value of 1.061, meaning that farmers have not received positive incentives from the current inputsubsidy policy. The impact of government policies on inputoutput as a whole was protective and provided positive incentives to farmers, but the value of the coefficient shows the level of protection that was still relatively weak and very vulnerable if there is a change in policy. The regional government is expected to provide protection to clove farmers in the form of setting the cost of clove purchases and also to exercise strict supervision of cartel practices in the clove trade system.
\end{abstract}

Keywords: Competitiveness; Government policy; Multi-period PAM

How to cite: Pratama, A.P., Darwanto, D.H, \& Masyhuri. 2020. The Impact of Government Poliices on The Competitiveness of Clove Commodity in Tolitoli Regency : Multi Period PAM Approach. Agro Ekonomi,31(1), x-xx

\section{INTRODUCTION}

In recent decades clove trade has been able to impact economic development in the Asian region (CortésRojas et al., 2014). However, clove plants in Indonesia currently face several challenges in its sustainability including competition in the conversion of land to other commodities such as oil palm and nutmeg (Santoso, 2019). In international trade, although Indonesia is known as the world's largest clove producer country, the competitiveness of Indonesia's clove commodities is still lagging behind other countries such as Madagascar and Comoros, one of the main causes is the low productivity (Pratama et al., 2020). Appropriate 
policies are urgently needed to support the sustainability of clove commodities which often face constraints on price instability, low productivity and challenges in meeting domestic and international needs (Indriyani et al., 2020).

Tolitoli Regency is one of the districts known as the Clove-producing Center in Central Sulawesi and even in Indonesia with an area of 37,720 ha with the highest production achievement in 2017 which reached $10,276.28$ tons. The realization of inter-island clove trade in Tolitoli in 2016 was $8,785.55$ tons, an increase of $35.87 \%$ compared to the conditions in 2015, where the realization of inter-island clove trade was only 5,634.1 tons (BPS Kabupaten Tolitoli, 2018).

Clove plants are plantations that have an important role in the economy of the community, especially farmers in Tolitoli Regency, but clove farmers are always faced with the classic problem that always makes farmers lose before the harvest, namely price fluctuation. According to Masengi et al. (2015) the characteristics of clove plants can only be harvested a maximum of 1 or 2 years and the harvest is 4 years, high production in a certain year will be followed by a decrease in the production of the next 1 or 2 years so that sometimes scarcity occurs but often there is also an oversupply so that prices often plummet.

In addition to the problem of low productivity, the problem of falling prices before the main harvest is often faced by clove farmers in Tolitoli Regency, this is due to monopsony market conditions. Wahyudi (2016a) stated that around $95 \%$ of clove production was used for the cigarette industry and the rest for food and spices. The large percentage of clove uptake by the kretek cigarette industry left farmers short of choices in marketing their products so that the cigarette industry had considerable authority in price monopolies. Currently Indonesia is also known as the main supplier of global clove essential oil to several countries in such as Saudi Arabia, India, Vietnam and United States (Bustaman, 2016). According to Kingu (2014) the motivation of farmers in maintaining clove plants is very much influenced by fluctuations in clove prices, especially in the export market.

Research related to the impact of government policies on the competitiveness of agricultural commodities using the Policy Analysis Matrix has been done quite a lot in Indonesia both for food crops, horticulture, and plantations, but prior research related to clove competitiveness and the impact of government policies is still lacking. This can be caused by clove being a plantation that has a long life span, so to conduct research and find out its competitiveness comprehensive data covering the age of the plant is needed. One of the studies that may be relevant to this research is a research conducted by (Indriyani et al., 2020) found out that clove farming had a comparative and competitive advantage but the government policies were disincentives to output, no protection policies for inputs, ineffective government incentive policies and no additional producer surpluses.

Based on the description of the above problems, the purpose of this 
study is to evaluate the impact of existing government policies on the clove plantation sector in Tolitoli Regency. The Policy Analysis Matrix (PAM) is a method of analysis approach that examines the effect of price policies and investment policies on agricultural productivity. The results of the PAM analysis can show both individual and collective effects of price policies and domestic factor policies. PAM also provides basic information that is important for BenefitCost Analysis for investment activities in agriculture (Pearson et al., 2005). The novelty of this study compared to the previous studies is that it employs a PAM multi-period approach which is a more in-depth analysis and is slightly different from a single PAM period because in a multi-period PAM the analysis is carried out based on the age of plants within longer period.

\section{METHODS}

The research location was chosen purposively, in which the research was conducted in Tolitoli Regency, Central Sulawesi Province with the consideration that Tolitoli Regency is the center of the largest clove commodity producers in Central Sulawesi, both in terms of production and land area. The multistage cluster sampling method was used to select Baolan District and Ogodeide District as a sample of research areas from 10 existing sub-districts with the consideration that the two Districts were the highest clove production centers in Tolitoli Regency. Samples were collected using the Slovin method (Prasada \& Masyhuri, 2019), based on the calculation of the Slovin method, from a population of 675 , a total sample of 87 people was obtained with a proportion of 65 respondents in Baolan District and 22 respondents in Ogodeide District.

The type of data used in this study was primary data and secondary data. Primary data was obtained directly from the source using a questionnaire from clove farmers, traders, experts related to clove agriculture, stakeholders, and clove agriculture institutions. Secondary data was obtained by collecting information in the form of documents and reports that can be obtained from the Central Statistics Agency, the Director-General of Plantations, the Plantation and Livestock Services Office of Tolitoli Regency, UNComtrade, Bank Indonesia and other supporting sources.

The data collected was then analyzed using the Policy Analysis Matrix (PAM) Method used to measure the impact of policies on producer income and identifying transfers between producers and consumers as the main actors involved in the agricultural system as well as policymakers in controlling government budget allocations. Stages carried out in PAM analysis included (1) determination of input-output in farming, (2) allocation of inputs into tradable and non-tradable components (3) method of determining shadow prices, (4) determining the competitiveness of a commodity in terms of excellence comparative (economic efficiency) and competitive advantage (financial efficiency) and the impact of government policy interventions on a commodity system (Table 1 ).

PAM table consisted of a revenue column, two input cost columns (tradable and non-tradable) and profit. 
The first line of the PAM matrix shows the calculation concerning the private price, that is, the actual price received or paid by the producer. The second line shows the calculation by referring to the social price or the shadow price which is the price that describes the real economic value of the input and output. The third line shows the transfer effect that illustrates theimpact of government policy on input-output and market failure (Suhardedi et al., 2017).

Table 1. Policy Analysis Matrix (PAM)

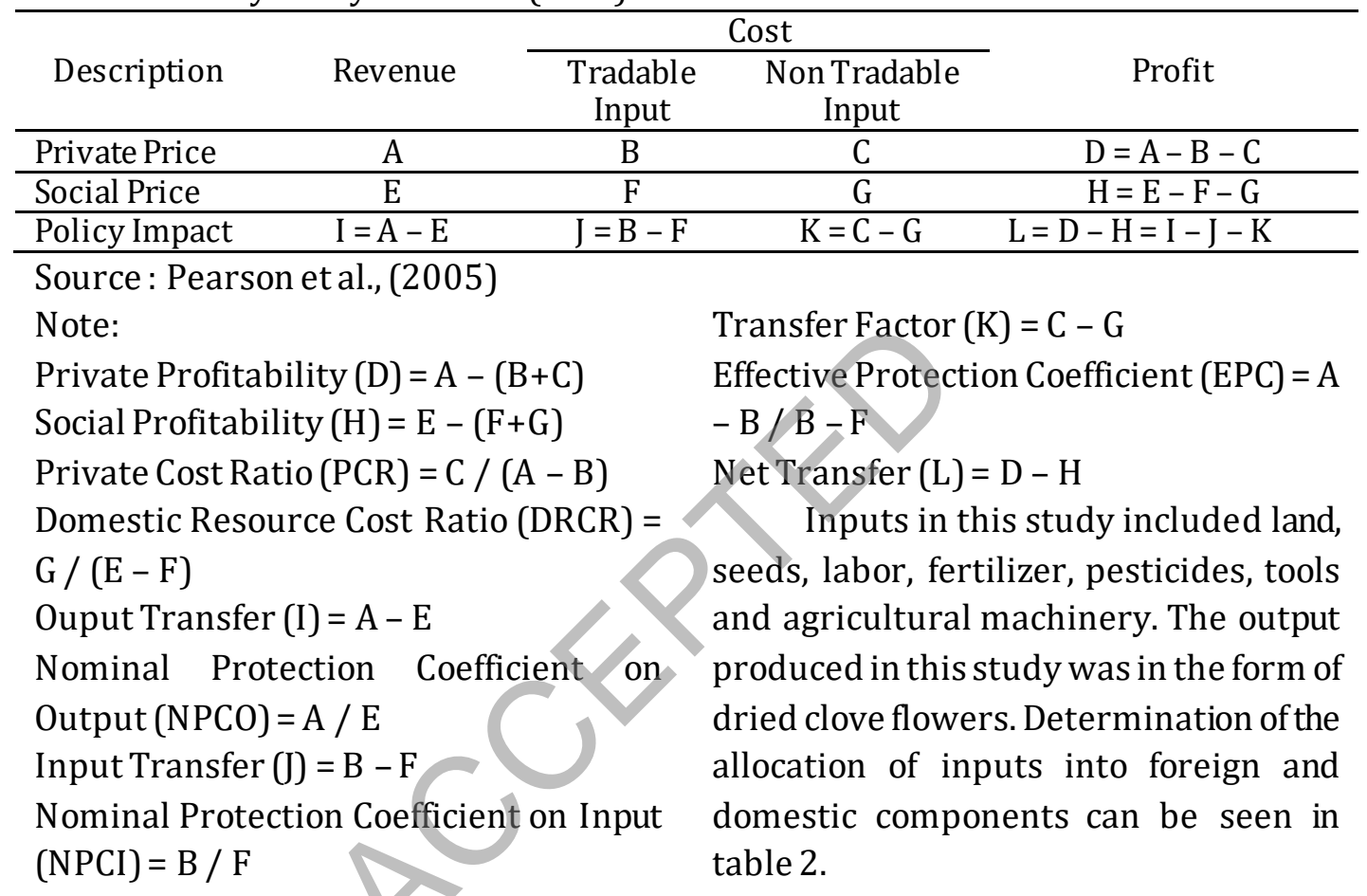

Table 2. Determination of Clove Farming Input Allocation into Domestic and Foreign Components

\begin{tabular}{lrr}
\hline Component & Domestic (\%) & Foreign (\%) \\
\hline Seeds & 100.00 & 0.00 \\
NPK- Phonska Fertilizer & $45.54^{*}$ & $54.46^{*}$ \\
Urea Fertilizer & $100.00^{*}$ & $0.00^{*}$ \\
ZA Fertilizer & $58.65^{*}$ & $41.35^{*}$ \\
SP-36 Fertilizer & $52.28^{*}$ & $47.72^{*}$ \\
Organic Fertilizer & 100.00 & 0.00 \\
Pesticide & $64.00^{* *}$ & $36.00^{* *}$ \\
Labor & 100.00 & 0.00 \\
Land & 100.00 & 0.00 \\
Equipment Depreciation & 100.00 & 0.00 \\
Transportation & $44.86^{* * *}$ & $55.14^{* * *}$ \\
\hline
\end{tabular}

Source: *(APPI, 2019); **Input-Output Indonesia (2008) in (Arfah et al., 2017), ${ }^{* * *}$ (Saputro et al., 2017)

Shadow prices or social prices are the prices formed in an economy under

conditions of perfect competition and equilibrium. Border price adjustment 
was calculated to determine shadow price. The shadow price for tradable commodities, both input, and output, was calculated using the FOB (Free on Board) limit approach, namely the price of goods arriving at the export port, while for imported commodities using the CIF (Cost Insurance Freight) price limit, namely the price of goods arriving at the import port. The method determining the Shadow Exchange Rate uses the Squire and Van der Tak methods (Gittinger, 1984) is shown in the below formula:

$$
\mathrm{SER}=\frac{\mathrm{OER}}{\mathrm{SCFt}}
$$

Where :

SER : Shadow exchange rate (IDR/US\$)

OER : Official exchange rate (IDR/US\$)

SCFt : Standard conversion factor

The SCF (Standard Conversion Factor) value is the ratio of the value of imports and exports plus tax which is formulated as follows:

Where :

$$
S C F t=\frac{X t+M t}{(X t-T x t)+(M t+T m t)}
$$

SCFt : Standard conversion factor for year - $t$

Xt : Indonesia's export value for year-t (IDR)

Mt : Indonesia'simport value for year-t (IDR)

Txt : Government revenue from export tax for year-t (IDR)

Tmt : Government revenue from import tax for year-t (IDR)

Clove plantations are annual plantations for plants that require a long period from the time of preparing the land, planting to harvest time whichmust reflect representative results that can describe the full competitiveness of cloves. Thus, it is necessary to apply a multi-period method PAM (Setiawan \& Sengadji, 2016). The PAM multi-period method requires calculating the total net present value (NPV) according to the economic age of the plant. Furthermore, the NPV formula used was as follows:

$$
\mathrm{NPV}=\sum_{\mathrm{t}=0}^{\mathrm{n}} \frac{\mathrm{Bt}-\mathrm{Ct}}{(1+\mathrm{i})^{\mathrm{t}}}
$$

Description:

$\mathrm{Bt}=$ Benefit for year $-\mathrm{t}$

$\mathrm{Ct}=$ Cost for year $-\mathrm{t}$

$1 /(1+\mathrm{i})^{\mathrm{t}}=$ Discount factor

$\mathrm{t}=\operatorname{year}(1,2,3, \ldots . \mathrm{n})$

$\mathrm{n}=$ farming period

Each NPV calculation model was applied to the private and social prices, then the results of the NPV calculation are entered into a single PAM matrix period for analysis based on PAM indicators in general. The results of the interpretation of the PAM single period and the multi-period PAM are the same, which show the total profit and divergence during that period (Pearson et al., 2005).

\section{RESULTS AND DISCUSSION}

Government policy can be one of the determinants of efficiency in economic activity. Among the policies that have been carried out by the government in the clove farming sector so far on the input side are input subsidies in the subsidized fertilizer program, while in terms of output there is no real policy in protecting the farmers in the face of clove price fluctuations in 
Table 3. Policy Analysis Matrix (PAM) of Clove Farming in Tolitoli Regency (IDR/Ha)

\begin{tabular}{lrrrr}
\hline \multirow{2}{*}{ Description } & \multirow{2}{*}{ Revenue } & \multicolumn{2}{c}{ Cost } & \multirow{2}{*}{ Profit } \\
\cline { 3 - 4 } & & Tradable Input & $\begin{array}{c}\text { Non Tradable } \\
\text { Input }\end{array}$ \\
\hline Private Price & $174,956,203$ & $20,271,805$ & $64,172,610$ & $90,511,787$ \\
Social Price & $160,783,171$ & $19,108,962$ & $58,372,308$ & $83,301,902$ \\
Policy Impact & $14,173,031$ & $1,162,843$ & $5,800,303$ & $7,209,885$ \\
\hline
\end{tabular}

Source: Primary Data Analysis, 2020

addition to the clove import ban policy

that it was implemented in 2002 which was revoked in 2015. This paper examines the efficiency of policies that take place in the clove farming sector with the Multi Period Policy Analysis Matrix approach

The PAM table used in this study was derived from the multi-period calculation of PAM by calculating the revenue, costs, and benefits according to the economic age of the plant for 20 years. The data then became an indicator of the competitiveness and policy impact of the clove farming system. The following table of PAM from the clove farming system for 20 years in Tolitoli Regency can be seen in Table 3.

\section{Competitive and Comparative Advantages of Clove Commodities in Tolitoli Regency}

The indicators used to determine the competitive and comparative advantage of a commodity were Private Cost Ratio (PCR) and Domestic Resources Cost Ratio (DRCR) (Mallu et al., 2018). PCR and DRCR values are also able to illustrate the efficiency of a farming system in terms of both financial and economic aspects. Financial efficiency describes the efficiency that occurs in private prices, while economic efficiency is based on the prices received or paid by farmers in conditions without market distortion (Nurwahidah et al., 2015). Values of PCR and DRCR of clove commodities in Tolitoli Regency for 20 years can be seen in Table 4 .

Table 4 shows that the value of the Privatee Cost Ratio (PCR) of clove commodities in Tolitoli Regency was 0.415 or less than one (PCR $<1$ ) which means clove commodities in Tolitoli Regency have competitive advantages and can compete at national and global levels even with the presence of government distortion or interference, the lower the value of PCR shows the stronger competitive competitiveness of a commodity. A PCR value of 0.415 can also be interpreted that to increase one unit of value-added output at the private price, it should incur additional domestic input costs at the private price of 0.415 (Haryanto et al., 2019).

Table 4. Indicators of Competitive and Comparative Excellence in Clove Farming in Tolitoli Regency

\begin{tabular}{lc}
\hline Indicators & Value \\
\hline Private Cost Ratio (PCR) & 0.415 \\
Domestic Resources Cost Ratio (DRCR) & 0.412 \\
\hline
\end{tabular}

Source: Primary Data Analysis, 2020 
The value of the Domestic Resources Cost Ratio (DRCR) of clove commodities in Tolitoli Regency was 0.412 or less than one (DRCR $<1$ ) which means that clove commodities in Tolitoli Regency have a comparative or economically efficient advantage with the assumption that in conditions there was no distortion or no government hand interference. It also shows that clove commodities are more profitable if they are produced domestically rather than imported from abroad because the production costs must be lower than if they must be imported (Putri et al., 2019). PCR value of 0.412 can also be interpreted that to produce one unit of cloves in the country only requires the cost of domestic input at a social price of 0.412 so that it will save on import costs of 0.588 .

\section{Impact of Output Policy}

The impact of government policies in Table 5 shows that the value of Output Transfer (OT) was positive (OT $>0$ ) in the amount of IDR. 14,173,031. This condition can be interpreted that the 20year government policy in the clove farming sector in Tolitoli Regency as a whole can provide positive incentives to farmers as producers and there has been a transfer from the consumer community to farmers or producers, even if it is examined further in some certain years there are policies that make farmers lose money many times and even they have to cut down their clove plants, such as the existence of BPPC in the 1990s and export-import regulations which were not so strict in controlling the entry of clove products from abroad into the country which often lowered prices at the farmer's level.

Nominal Protection Coefficient Output (NPCO) based on Table 5 shows that the value of NPCO was greater than one (NPCO $>1$ ) that was equal to 1.088 . It shows that the government policy on clove farming in Tolitoli Regency for 20 years was protective or this reflects that the overall price of domestic output was higher than the output price at the international level. Although the overall policy was protective, the NPCO value was almost close to the number one that reflects that the level of protection still tends to be weak. The role of the local government is also needed in this regard to encourage the community motivation to properly maintain the clove plants. It is because Tolitoli Regency ranks first in producing cloves in Indonesia in terms of production since 2016 (Direkorat Jenderal Perkebunan, 2017).

The fact occurred at the study site shows that the level of protection from the Tolitoli Regional Governmentagainst clove farmers on their own clove products tends to be weak. Trading conditions at the regional level where there are only one or two large traders who have the authority to export cloves out of the region make the market

Table 5. Indicators of Policy Impacts on Clove Farming Output in Tolitoli Regency

\begin{tabular}{lr}
\hline Indicators & Value \\
\hline Output Transfer (OT) & $14,173,031$ \\
Nominal Protection Coefficient Output(NPCO) & 1.088 \\
\hline
\end{tabular}

Source: Primary Data Analysis, 2020 
structure become monopsonistic and suppress prices at the farm level, triggering price disparity.

It requires several elements of the community such as farmers, farmer organizations, and Non-Governmental Organizations (NGOs) to voice these conditions to the government so that the local government issues a regulation through Decree of the Regent No. 337 2019 on July 16, which sets the standard cost of clove purchases at IDR 100,000 / $\mathrm{kg}$. Since the issuance of the decree, there have not been any concrete steps taken by the regional government to realize this, so what has happened to date has remained following market mechanisms.

According to Siregar (2011) clove is a commodity that is very vulnerable to price fluctuations, clove prices can surge up to $200 \%$ and vice versa can drop dramatically in a percentage that does not differ much from the increase. The Ind onesian Government once limited the import of cloves through Regulation of the Minister of Industry and Trade No. 7 of 2002 even though this contradicted the World Trade Organization agreement (Suprihanti et al., 2018).

The impact of the policy makes the price of cloves reach IDR $120,000 / \mathrm{kg}$ IDR $130,000 / \mathrm{kg}$, however in 2015 the government re-issued a policy in the Minister of Trade Regulation of (Permendag) Number 75 of 2015 which regulates the liberalization of clove imports so that the price of cloves in the country dropped to IDR $70,000 / \mathrm{kg}$. According to the Indonesian Clove Farmers Association (APCI), it is considered to be very pressing and detrimental to the clove farmers because it causes domestic clove prices to be low and farmers lose the opportunity to enjoy the proper price they should have obtained.

\section{Impact of Input Policies}

The impact of government policies in Table 6 shows that the value of Input Transfer (IT) was positive (IT>0) in the amount of IDR $1,162,843$, in which the cost of private tradable inputs was greater than the costs of social tradable inputs. It shows that there was a transfer from producer farmers to tradable input producers meaning that farmers have to pay more to obtain tradable inputs.

This condition is certainly in conflict with or not in line with the input subsidy policy that has been set by the government in the form of a subsidized fertilizer program since 2003 through the Minister of Industry and Trade Decree Number 70 / MPP / Kep / 2/2003 to support efforts to achieve agricultural production targets. The types of fertilizers included in the subsidized fertilizer category include Urea, NPKPhonska, SP36, ZA, and organic fertilizer, but the policies implemented by the government to provide incentives to farmers often occur that subsidies were not on target and in distribution there was often smuggling (Darwis \& Supriyati, 2014). Existing input subsidy policies have not been able to provide positive incentives for the clove farming system in Tolitoli Regency for 20 years. Frequent fraud and misuse of subsidized fertilizer in the field make it often difficult for farmers to obtain fertilizer and if available the price is higher than it should be (Hasibuan et al., 2012). 
Table 6. Indicators of Policy Impacts on Clove Farming Inputin Tolitoli Regency

\begin{tabular}{lr}
\hline Indicators & Value \\
\hline Input Transfer (IT) & $1,162,843$ \\
Nominal Protection Coefficient Input (NPCI) & 1.061 \\
Transfer Factor (TF) & $5,800,303$ \\
\hline
\end{tabular}

Source: Primary Data Analysis, 2020

Nominal Protection Coefficient Input (NPCI) based on Table 6 shows that the value of NPCI was greater than one (NPCI>1), which was 1.061. It shows that farmers must incur more expensive input costs because the price of domestic tradable input is higher than the price of tradable input at the international level (Haryono et al., 2011). Domestic tradable input prices were $6.1 \%$ more expensive than tradable input prices at the international level. Overall, the government's policy towards tradable input of clove farming in Tolitoli Regency for 20 years was unprotective or had not been able to provide positive incentives for tradable inputs in the clove farming system.

Based on Table 6 shows that the TF value was positive $(\mathrm{TF}>0)$ in the amount of IDR 5,800,303, it in dicates that there is a transfer from producer farmers to nontradable input producers or farmers must pay higher costs because there were negative subsidies in the form of taxes clove farmers must bear the non tradable inputs. Components of nontradable input costs that required higher costs by clove farmers at the study site are labor costs and harvesting equipment in the form of bamboo ladders. This is because the availability of labor or harvest workers available at the study site was increasingly scarce, so farmers often brought in labor from the

subdistrict or neighboring district causing wages to rise, as well as harvesting tools for farmers who still used traditional tools such as bamboo ladders which recently are increasingly hard to find.

\section{Impact of Input - Output Policies}

The Effective Protection Coefficient (EPC) coefficient is useful to know the extent of the impact of government policy in supporting or hampering farmers in their farm management. Based on Table 7 it is known that the value of the EPC was more than one (EPC>1) of 1.092, which means if it is accumulated for the whole 20 years, the government policy was protective for the clove farming system in Tolitoli Regency. As one of the largest clove producing regions in Indonesia, the government should support the sustainability of the farming system so that it continues to produce. This certainly needs to be synchronized between the central government and regional governments in a tangible form.

Table 7 shows that the Net Transfer value of clove farming in Tolitoli Regency was positive (NT>0) in the amount of IDR 7,209,885, which means that governmentpolicies were protective for the clove farming system and farmers get a producer surplus of IDR.7,209,885 from the policy which exists. 
Table 7. Indicators of Policy Impacts on Clove Farming Input and Output in Tolitoli Regency

\begin{tabular}{lr}
\hline Indicators & Value \\
\hline Effective Protection Coefficient (EPC) & 1.092 \\
Net Transfer (NT) & $7,209,885$ \\
\hline
\end{tabular}

Source: Primary Data Analysis, 2020

The weak level of protection will be very vulnerable to the threat of policy distortion, the entry of imported products of the same type at lower prices needs to be watched by the government as a regulator of policy makers with due regard to tax regulations and subsidies (Dos Santos Alves et al., 2017). The characteristics of clove production which fluctuated every year also need to be reviewed by applying supply chain management so that production fluctuations do not have a significant effect on falling clove prices at the farmer level Wahyudi (2016b).

\section{CONCLUSION AND SUGGESTION}

The clove farming system in Tolitoli Regency for 20 years has shown that clove commodities had competitiveness in terms of competitive or comparative advantage. The impact of government policies on the output of clove farming in Tolitoli was protective, but tent to be weak and needed to be strengthened. While on the other hand the impact of government policies on clove farming inputs was unprotective, meaning that farmers had not received positive incentives from the current input subsidy policy. The impact of government policies on input-output as a whole was protective and provided positive incentives to farmers, but the the coefficient that tent to approach the efficient limit indicates the level of protection that was still relatively weak and very vulnerable if there was a change in policy.

The regional government is expected to be able to provide protection to farmers as the main producers of cloves in the form of interventions to determine the clove floor prices and supervising the implementation. The regional government must carry out strict supervision on cartel practices in the clove trade system which causes the clove market to be monopsony and evaluate the fertilizer subsidy policy by replacing the application of the farmer card mechanism so that the benefits of the subsidies are immediately felt by farmers and intensifyingand supervising the distribution of subsidized fertilizer to the farmer level.

\section{REFERENCES}

APPI.

Supply_and_Demand_2007_-_2018.

Retrieved from http://appi.or.id/?statistic

Arfah, S. Y. C., Harianto, \& Suharno. (2017). Daya Saing Dan Peran Pemerintah Dalam Meningkatkan Daya Saing Komoditi Kakao Di Sulawesi Tengah. Buletin Ilmiah Litbang Perdagangan, 11(1), 69-96. https://doi.org/10.30908/bilp.v11 i1.79

BPS Kabupaten Tolitoli. (2018). Kabupaten Tolitoli Dalam Angka 2017. Badan Pusat Statistik Kabupaten Tolitoli.

Bustaman, S. (2016). Potensi Pengembangan Minyak Daun Cengkih sebagai Komoditas Ekspor Maluku. Jurnal Penelitian Dan 
Pengembangan Pertanian, 30(4), 132-139.

https://doi.org/10.21082/jp3.v30 n4.2011.p132-139

Cortés-Rojas, D. F., de Souza, C. R. F., \& Oliveira, W. P. (2014). Clove (Syzygium aromaticum): A precious spice. Asian Pacific Journal of Tropical Biomedicine, 4(2), 90-96. https://doi.org/10.1016/S22211691(14)60215-X

Darwis, V., \& Supriyati. (2014). Subsidi Pupuk: Kebijakan, Pelaksanaan, dan Optimalisasi Pemanfaatannya. Analisis Kebijakan Pertanian, 11(1), 45.

https://doi.org/10.21082/akp.v11 n1.2013.45-60

Direkorat Jenderal Perkebunan. (2017). Statistik Perkebunan Indonesia; Cengkeh 2016-2018. Retrieved from http://ditjenbun.pertanian.go.id

Dos Santos Alves, C. E., Belarmino, L. C., \& Padula, A. D. (2017). Feedstock diversification for biodiesel production in Brazil: Using the Policy Analysis Matrix (PAM) to evaluate the impact of the PNPB and the economic competitiveness of alternative oilseeds. Energy Policy, 109(July), 297-309. https://doi.org/10.1016/j.enpol.20 17.07.009

Gittinger, J. P. (1984). Economic Analysis of Agricultural Projects. London: The Johns Hopkins University Press.

Haryanto, L. I., Masyhuri, M., \& Irham, I. (2019). The Policy Analysis Matrix in Measuring Competitiveness of Maize Farming System in Marginal Areas. Agro Ekonomi, 29(2), 244. https://doi.org/10.22146/ae.3596 4

Haryono, D., Soetriono, S., Hartadi, R., \& Mulyo Aji, J. M. (2011). Analisis Daya Saing Dan Dampak Kebijakan Pemerintah Terhadap Produksi Kakao Di Jawa Timur. Jurnal Sosial Ekonomi Pertanian, 5(2), 72-82.
Retrieved from http://jurnal.unej.ac.id/index.php/ JSEP/article/view/375

Hasibuan, A. M., Sudjarmoko, B., \& Listyati, D. (2012). Analisis Keunggulan Komparatif dan Kompetitif Usahatani Pala ( Studi Kasus: Kabupaten Bogor dan Sukabumi ). Buletin RISTRI. Balai Penelitian Tanaman Industri Dan Penyegar, 3(3), 223-230. https://doi.org/10.21082/jtidp.v3 n3.2012.p223-230

Indriyani, N., Prajanti, S. D. W., \& Maretta, Y. A. (2020). Competitiveness and The Impact of Government Policy on The Clove Farming Business in Getasan Sub-District, Semarang Regency. International Journal of Scientific and Technology Research, 9(1), 3173-3182.

Kingu, J. (2014). Cloves Export Response to trade liberalization in Tanzania: A Cointegration Analysis. Journal of Economics and Sustainable Development, 5(1), 99-120.

Mallu, M. H., Darwanto, D. H., Hartono, S., \& Handoyo Mulyo, J. (2018). The Competitiveness of Beef Cattle Breeding Business on Community Livestock-Based in North Penajam Paser Regency, East Kalimantan Province. International Journal of Economics \& Management Sciences, 07(05), 5-8. https://doi.org/10.4172/21626359.1000548

Masengi, C., Pakasi, C. B. D., \& Olfie, B. (2015). Peningkatan Aktifitas Petani Cengkeh di Wilayah Desa Toulimembet Kecamatan Kakas. EJournal UNSRAT, 1-31.

Nurwahidah, S., Hadi Darwanto, D., Masyhuri, \& Waluyati, L. R. (2015). Efficiency and Competitiveness of Corn Farming in Sumbawa Regency. IOSR Journal of Agriculture and Veterinary Science Ver. I, 8(11), 2319-2372. 
https://doi.org/10.9790/2380081113947

Pearson, S., Gotsch, C., \& Bahri, S. (2005). Aplikasi Policy Analysis Matrix Pada Pertanian Indonesia (I). Jakarta: Yayasan Obor Indonesia.

Prasada, I. Y., \& Masyhuri, M. (2019). Farmers' Willingness to Accept a Compensation to Protect Agricultural Land Sustainability in Peri-Urban Areas of Pekalongan City. Agro Ekonomi, 30(2). https://doi.org/10.22146/ae.4886 9

Pratama, A. P., Darwanto, D. H., \& Masyhuri, M. (2020). Indonesian Clove Competitiveness and Competitor Countries in International Market. Economics Development Analysis Journal, 9(1), 39-54.

https://doi.org/10.15294/edaj.v9i 1.38075

Putri, T. W. S., Suryantini, A., \& Utami, A. W. (2019). The Competitiveness of Stevia rebaudiana as A Sweetener Alternative in Tawangmangu Subdistrict of Karanganyar Regency. Agro Ekonomi, XX(X), 1020.

https://doi.org/http://doi.org/10. 22146/ae.46979

Santoso, A. B. (2019). Perspektif Peningkatan Daya Saing Cengkeh Maluku Dengan Indeks Keberlanjutan Sistem Agribisnis. Jurnal Litbang Pertanian, 38(2), 114-122.

Saputro, W. A., Masyhuri, M., \& Suryantini, A. (2017). Analysis Competitiveness of Sugarcane Farming in Central Java and East Java. Agro Ekonomi, 28(2), 237. https://doi.org/10.22146/jae.2759 5

Setiawan, K., \& Sengadji, H. M. (2016). Analisis Dampak Kebijakan Pemerintah Terhadap Daya Saing Komoditas Kelapa di Kabupaten Flores Timur. Agrica (Jurnal Agribisnis Sumatera Utara), 9(2), 80-89. Retrieved from http://ojs.uma.ac.id/index.php/agr ica

Siregar, A. R. (2011). Analisis Disparitas Harga dan Potensi Persaingan Tidak Sehat pada Distribusi Cengkeh. Jurnal Agribisnis, 10(3), 32-37.

Suhardedi, C., Darwanto, D. H., \& Irham. (2017). Competitiveness Rice Farming In Sragen Regency. Agro Ekonomi, 28(1), 19. https://doi.org/10.22146/jae.2458 4

Suprihanti, A., M. Sinaga, B., Harianto, H., \& Kustiari, R. (2018). The Impact of Clove Import Policy on Clove Market and Cigarette Production in Indonesia. Advance in Engineering Research, 172(4th International Conference on Food and Agriculture Resources FANRes), 274-279. https://doi.org/10.2991/fanres18.2018 .55

Wahyudi, A. (2016a). Analisis Finansial dan Skema Pembiayaan Program Peremajaan, Rehabilitasi dan Intensifikasi Cengkeh. Jurnal Littri, 22(3), 142-150. https://doi.org/10.21082/littri.v2 2n3.2016.142-150

Wahyudi, A. (2016b). Strategi Stabilisasi Kinerja Pasar Cengkeh Nasional. Balai Penelitian Tanaman Rempah Dan Obat, 15(1), 73-86. 